\title{
Assessment of Groundwater Pollution Due to Textile Industrial Activities in and Around Tirupur Region, Tamil Nadu, India
}

\author{
K. Arumugam*†, T. Karthika*, K. Elangovan** and A. Rajesh Kumar*** \\ *Department of Civil Engineering, Kongu Engineering College, Perundurai-638 060, Tamil Nadu, India \\ **Department of Civil Engineering, PSG College of Technology, Coimbatore-641 004, Tamil Nadu, India \\ ***GBH International Construction, Pvt. Ltd., Dubai \\ $\dagger$ Corresponding author: K. Arumugam; sixface@kongu.ac.in
}

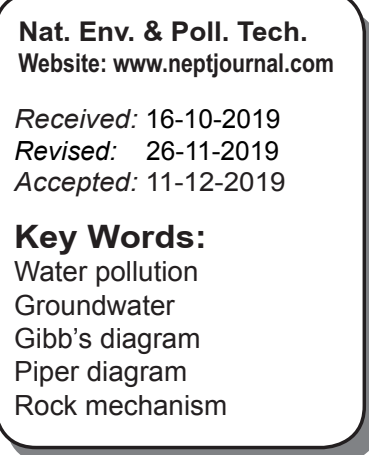

Nat. Env. \& Poll. Tech.

Revised: $26-11-2019$

Key Words:

Water pollution

Groundwater

Piper diagram

\begin{abstract}
Groundwater is the most important resource for human consumption and the support of habitat and for maintaining the feature of base flow to river courses, while its quality is necessary to ensure sustainable safe exploit of the resources for all purposes. The untreated or inappropriate industrial effluents discharge on the surface causes harsh groundwater pollution in the industrial area of the nation. Sixty groundwater samples have been collected from boreholes and water samples were analysed to examine the groundwater quality of Avinashi-Tirupur-Palladam region. The samples were examined for the physico-chemical parameters like $\mathrm{pH}$, electrical conductivity (EC) and total dissolved solids (TDS), major cations like calcium $\left(\mathrm{Ca}^{2+}\right)$, magnesium $\left(\mathrm{Mg}^{2+}\right)$, sodium $\left(\mathrm{Na}^{+}\right)$, potassium $\left(\mathrm{K}^{+}\right)$and major anions like bicarbonate $\left(\mathrm{HCO}_{3}^{-}\right)$, carbonate $\left(\mathrm{CO}_{3}{ }^{2-}\right)$, chloride $\left(\mathrm{Cl}^{-}\right)$, nitrate $\left(\mathrm{NO}_{3}{ }^{-}\right)$and sulphate $\left(\mathrm{SO}_{4}{ }^{2-}\right)$, along with fluoride. The abundance of major cations and anions was investigated. Spatial distribution map based on total dissolved solids indicates that the Noyyal and Nallar river basins, central regions of the study area, are more affected. The chemical parameter data of groundwater samples of the study area are plotted in Gibbs's diagram. Based on the Piper diagram, different water types were identified. Hydro-chemically, the quality of the groundwater for human consumption was determined. The ion concentration distribution indicates that most of the groundwater sample locations in the study area are not suitable for domestic use.
\end{abstract}


nologies such as remote sensing and GIS have proved to be valuable for understanding the geological environment and geomorphologic conditions accompanied by conventional survey systems (Solomon \& Quiel 2006). It is familiar that a contaminated environment has a detrimental effect on the health of people, life of animal and vegetation. During the last few years, there has been information about undesirable changes in the quality of groundwater by the people inhabiting the study area (Sujatha \& Reddy 2003).

\section{MATERIALS AND METHODS}

The study area lies between latitudes $1100^{\circ} 10^{\circ}$ " $\mathrm{N}-1130^{\prime} 12^{\circ}$ " $\mathrm{N}$ and longitudes 7700 ' $10^{\circ}$ " E-7730 '28 ${ }^{\circ}$ " E (Fig. 1) with a geographical area of $450 \mathrm{~km}^{2}$. The study area accounts for $90 \%$ of India's cotton knitwear export value estimated as 3,500 crores. Tirupur is the prime garment exporter in India and it is referred to as the textile valley of India. The study area covers Tirupur taluk, parts of Avinashi and Palladam taluks which are characterized by undulating terrain with the height ranging between 290 and 320 meters above the mean sea level and slanting gradually from west to east direction. The Noyyal river runs all across the study area, almost dividing it into two halves. The various types of soils of the study area are red calcareous, brown soil and non-calcareous soil. Geologically, the area is underlain by a broad range of high-grade metamorphic gneissic complex (Arumugam et al. 2015). The drainage pattern is the dendritic form (Fig. 2 ) and they have been found to continue from the Western Ghats. NE-SE trending lineaments are less in number and observed at wide intervals. The geomorphic units exposed from the study area are pediments, shallow pediments, duricrust and shallow buried pediments. The common rock type of the area is hornblende-biotite-gneisses (unclassified gneiss) pink granite, charnockite and complex gneiss along with alluvial rocks and limestones (Fig. 3).

For assessing the groundwater pollution, 62 groundwater samples from the boreholes have been collected and analysed for physico-chemical parameters such as $\mathrm{pH}$, electrical conductivity (EC) and total dissolved solids (TDS), major cations viz., calcium $\left(\mathrm{Ca}^{2+}\right)$, magnesium $\left(\mathrm{Mg}^{2+}\right)$, sodium $\left(\mathrm{Na}^{+}\right)$, potassium $\left(\mathrm{K}^{+}\right)$and major anions viz. bicarbonate $\left(\mathrm{HCO}_{3}{ }^{-}\right)$, carbonate $\left(\mathrm{CO}_{3}{ }^{2-}\right)$, chloride $\left(\mathrm{Cl}^{-}\right)$, nitrate $\left(\mathrm{NO}_{3}{ }^{-}\right)$and sulphate $\left(\mathrm{SO}_{4}{ }^{2-}\right)$, in the laboratory by the standard methods given by the American Public Health Association (APHA 1995). The groundwater sample locations were selected for covering the entire study area and attention was given to the

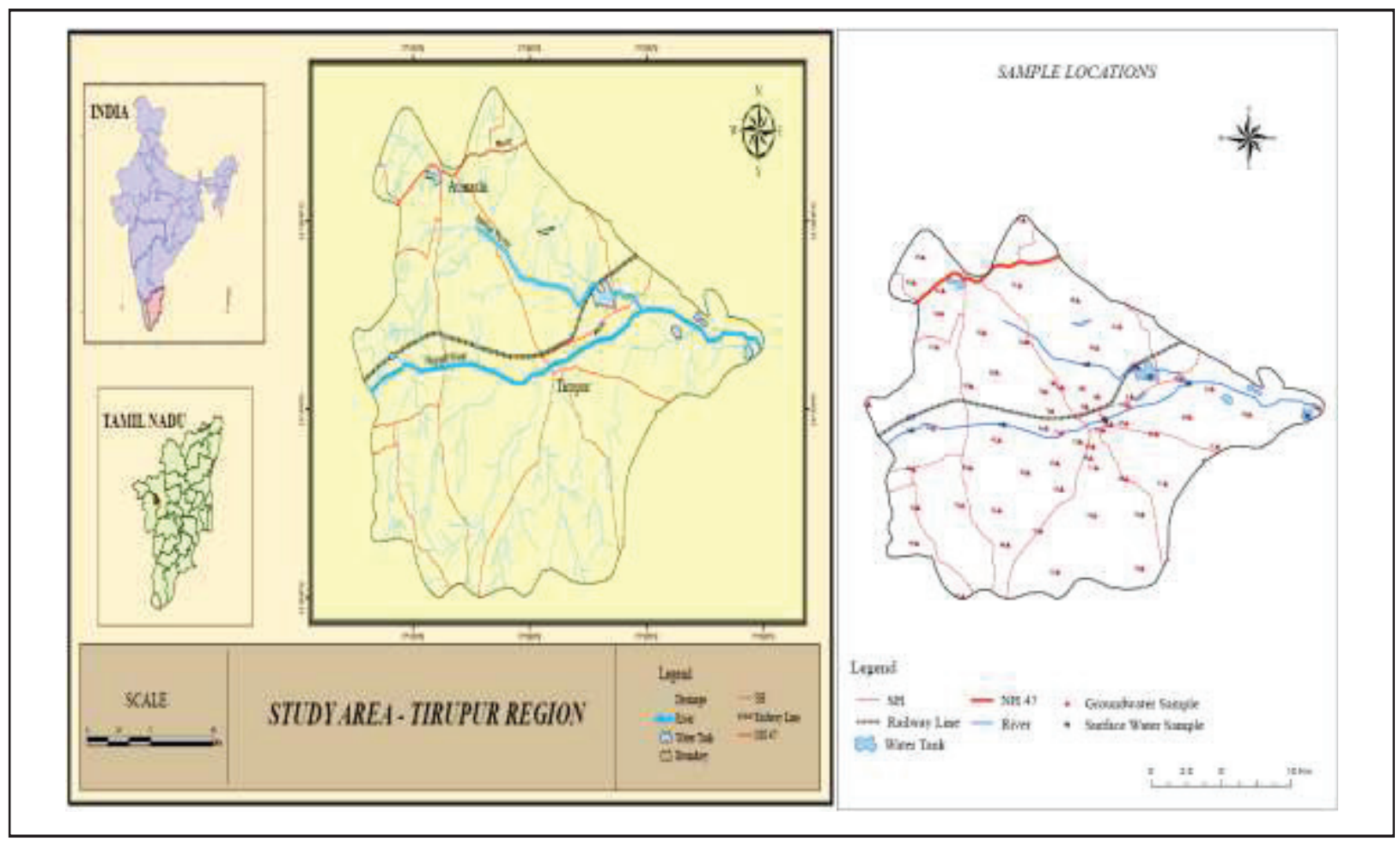

Fig. 1: Sample locations of the study area. 
areas where toxic waste is expected. About one-third of the sampling stations are within the Tirupur city area and the remaining sampling stations are parts of Palladam and Avinasi taluks. Sampling was conceded using pre-cleaned polyethylene containers. The groundwater samples were evaluated following the drinking water quality standards given by the World Health Organization (WHO 1993) and Bureau of Indian Standards (ISI 2012). The solution of groundwater should be electrically neutral. However, they are rarely equal in practice. The variation increases as the ion concentration value increases (Raju 2006). The exactness of the chemical analysis was verified by calculating ion-balance errors where the errors are generally about 10\% (Subramani et al. 2005).

\section{RESULT AND DISCUSSION}

To evaluate the quality of subsurface water to find its suitability for domestic purposes, groundwater samples were collected from the study area. The major issue which decides the quality of its groundwater in the study area is textile industrial units and their processes. The water quality may give information about the environment through which the water has disseminated. The results of the analytical data of the chemical parameters and the statistical parameters such as minimum, maximum, mean and median are given in Table 1. For understanding the distribution pattern of the different ion concentration of the parameters, contour maps were generated. Electrical conductivity (EC) values ranged from $847 \mu \mathrm{S} / \mathrm{cm}$ to $9,940 \mu \mathrm{S} / \mathrm{cm}$ with mean and median values of $2,738 \mu \mathrm{S} / \mathrm{cm}$ and $2,235 \mu \mathrm{S} / \mathrm{cm}$ respectively. The

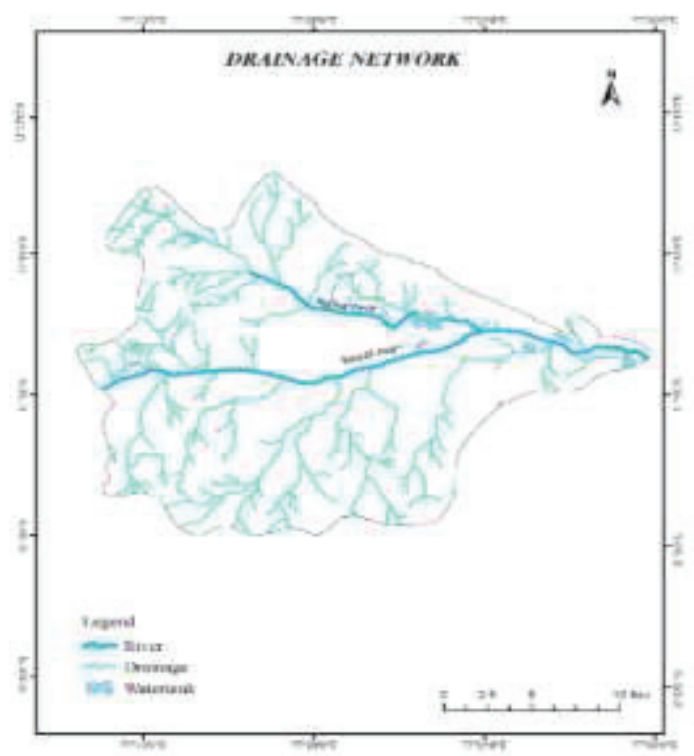

Fig. 2: Drainage network of the study area. large disparity in EC is mostly attributed to anthropogenic activities and the geochemical course prevailing the region. The values of $\mathrm{pH}$ ranged from 6.62 to 8.26 with an average value of 7.71. The values show that the samples of the groundwater of the study area are mostly alkaline. However, in all the sample locations, the $\mathrm{pH}$ of the groundwater is within the permissible limits.

To determine the appropriateness of groundwater for any purpose, it is essential to categorize the groundwater based on its hydro-chemical properties like TDS values (Davis \& Dewiest 1996, Freeze \& Cherry 1979). The total dissolved solids of the groundwater samples have ranged from 550 to $5,998 \mathrm{mg} / \mathrm{L}$ with the average and median values of $1,771 \mathrm{mg} / \mathrm{L}$ and $1,552 \mathrm{mg} / \mathrm{L}$. This overall evaluation of mean and median values indicates that the water in the study area is unfit for drinking purpose. The spatial distribution map for the TDS prepared using GIS software is illustrated in Fig. 4. The study indicates that all the groundwater samples exceed the desirable limit of $500 \mathrm{mg} / \mathrm{L}$. Moreover, Noyyal and Nallar river basins are highly affected by different anthropogenic activities.

The concentration of cations $\mathrm{Ca}^{2+}, \mathrm{Mg}^{2+}, \mathrm{Na}^{+}$and $\mathrm{K}^{+}$ions ranged from 2 to 915,0 to 485,25 to 1,123 and 7 to $271 \mathrm{mg} / \mathrm{L}$ with a mean of 168, 94, 226 and $69 \mathrm{mg} / \mathrm{L}$ respectively. The order of abundance of the cations is $\mathrm{Ca}^{2+}>\mathrm{Mg}^{2+}>\mathrm{Na}^{+}>$ $\mathrm{K}^{+}$. The anion concentrations, $\mathrm{HCO}_{3}{ }^{-}, \mathrm{SO}_{4}{ }^{2-}, \mathrm{Cl}^{-}, \mathrm{NO}_{3}{ }^{-}$and $\mathrm{CO}_{3}{ }^{-}$range from 140 to 789,0 to 1215,36 to 3195,0 to 572 and 0 to $282 \mathrm{mg} / \mathrm{L}$ with a mean of $413,162,548,78$ and $54 \mathrm{mg} / \mathrm{L}$ respectively. The order of dominance of anions is $\mathrm{Cl}^{-}>\mathrm{HCO}_{3}{ }^{-}>\mathrm{SO}_{4}{ }^{2-}>\mathrm{NO}_{3}{ }^{-}>\mathrm{CO}_{3}$. Hydro-geochemical

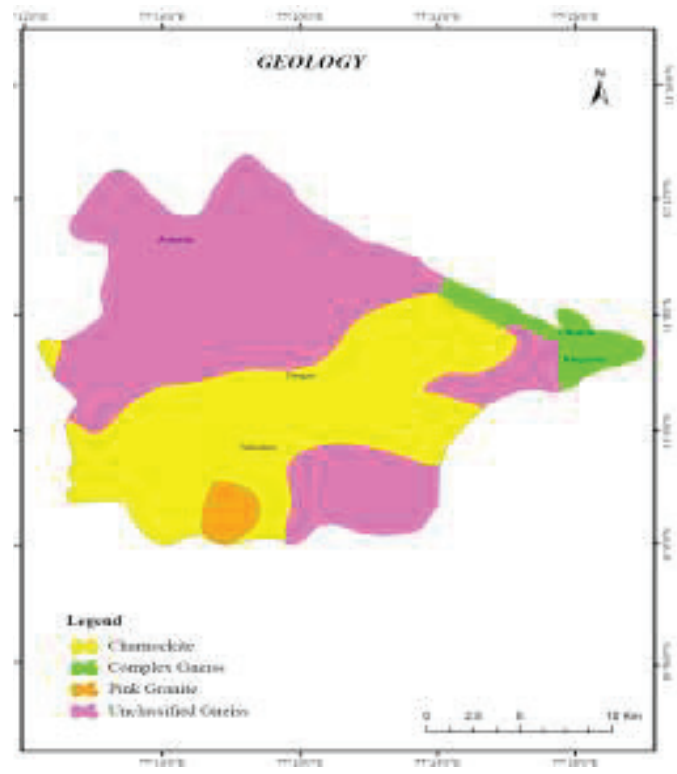

Fig. 3: Geology of the study area. 
Table 1: Drinking water specifications given by ISI (2012) and WHO (1993), and summary statistics of groundwater parameters.

\begin{tabular}{|c|c|c|c|c|c|c|}
\hline Water quality parameters & $\begin{array}{l}\text { ISI (2012) } \\
\text { Maximum } \\
\text { permissible }\end{array}$ & $\begin{array}{l}\text { WHO (1993) } \\
\text { Maximum } \\
\text { permissible }\end{array}$ & $\begin{array}{l}\text { Minimum } \\
\text { concentration }\end{array}$ & $\begin{array}{l}\text { Maximum } \\
\text { concentration }\end{array}$ & Mean & Median \\
\hline $\mathrm{EC}(\mu \mathrm{S} / \mathrm{cm})$ & - & - & 847 & 9,940 & 2,738 & 2,235 \\
\hline $\mathrm{pH}$ & $6.5-9.2$ & $6.5-9.5$ & 6.62 & 8.26 & 7.71 & 7.55 \\
\hline TDS (mg/L) & 1,500 & 1,500 & 550 & 5,998 & 1,771 & 1,552 \\
\hline $\mathrm{TH}$ as $\mathrm{CaCO}_{3}(\mathrm{mg} / \mathrm{L})$ & 600 & 500 & 214 & 3,610 & 788 & 627 \\
\hline $\mathrm{Ca}^{2+}(\mathrm{mg} / \mathrm{L})$ & 200 & 200 & 29 & 915 & 168 & 128 \\
\hline $\mathrm{Mg}^{2+}(\mathrm{mg} / \mathrm{L})$ & 100 & 150 & 0 & 485 & 94 & 75 \\
\hline $\mathrm{Na}^{+}(\mathrm{mg} / \mathrm{L})$ & - & 200 & 25 & 1,123 & 226 & 159 \\
\hline $\mathrm{K}^{+}(\mathrm{mg} / \mathrm{L})$ & - & 12 & 7 & 271 & 69 & 52 \\
\hline $\mathrm{HCO}_{3}^{-}(\mathrm{mg} / \mathrm{L})$ & 300 & - & 140 & 789 & 413 & 398 \\
\hline $\mathrm{CO}_{3}{ }^{2-}(\mathrm{mg} / \mathrm{L})$ & - & - & 0 & 282 & 54 & 28 \\
\hline $\mathrm{Cl}^{-}(\mathrm{mg} / \mathrm{L})$ & 1,000 & 600 & 36 & 3,195 & 548 & 396 \\
\hline $\mathrm{NO}_{3}^{-}(\mathrm{mg} / \mathrm{L})$ & - & 45 & 0 & 572 & 78 & 61 \\
\hline T. Alk (mg/L) & 600 & - & 211 & 734 & 435 & 429 \\
\hline $\mathrm{SO}_{4}{ }^{2-}(\mathrm{mg} / \mathrm{L})$ & 400 & 400 & 0 & 1,215 & 162 & 99 \\
\hline $\mathrm{F}^{-}(\mathrm{mg} / \mathrm{L})$ & 1.2 & 1.5 & 0 & 2.11 & 0.71 & 0.61 \\
\hline
\end{tabular}

processes such as ion exchange processes, precipitation, and the residence instance along the flow path control the chemical composition of the region (Nwankwoala \& Udom 2011). Process of evaporation increases salinity by increasing sodium and chloride with the increase of TDS. Lack of good drainage setting, semi-arid climate conditions, gentle slope, and residence time of the groundwater also contribute to the quality of groundwater (Subba Rao 2006). According to Gibb's diagram the ratio of $\mathrm{Na}^{+}:\left(\mathrm{Na}^{+}+\mathrm{Ca}^{2+}\right)$ and $\mathrm{Cl}^{-}:\left(\mathrm{Cl}^{-}+\right.$
$\left.\mathrm{HCO}_{3}{ }^{-}\right)$is a function of TDS. It is extensively used to review the functional sources of dissolved chemical parameters such as evaporation-dominance, precipitation-dominance and rock-dominance (Gibbs 1970). The data of the groundwater samples of the study area are plotted in Gibbs's diagram. The distribution of the groundwater sample locations suggests that the chemical weathering of rock-forming minerals and evaporation control the quality of groundwater in the study region (Fig. 5).

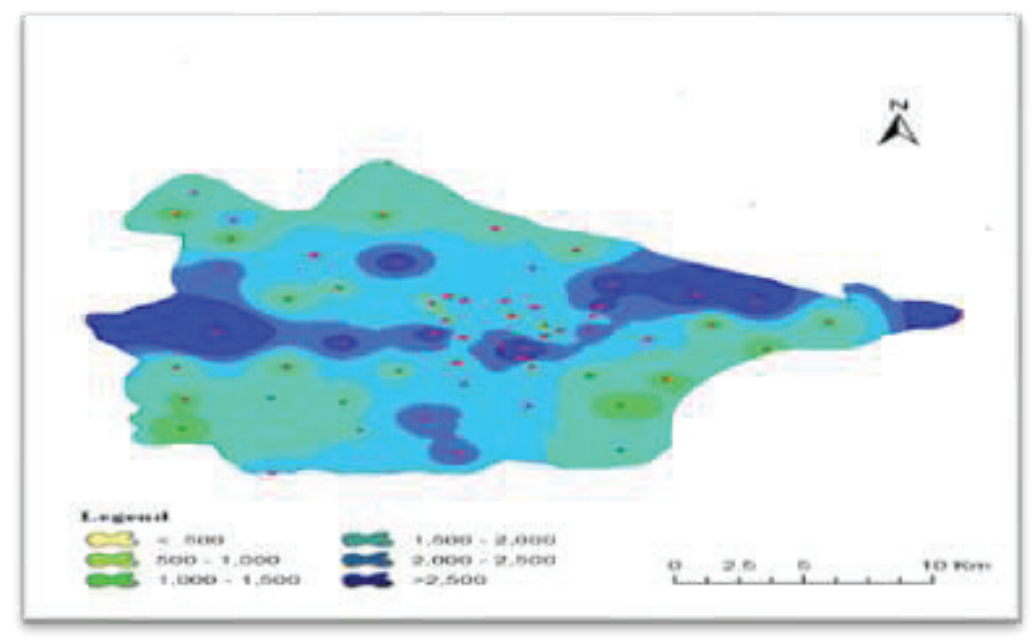

Fig. 4: Spatial variation of total dissolved solids. 

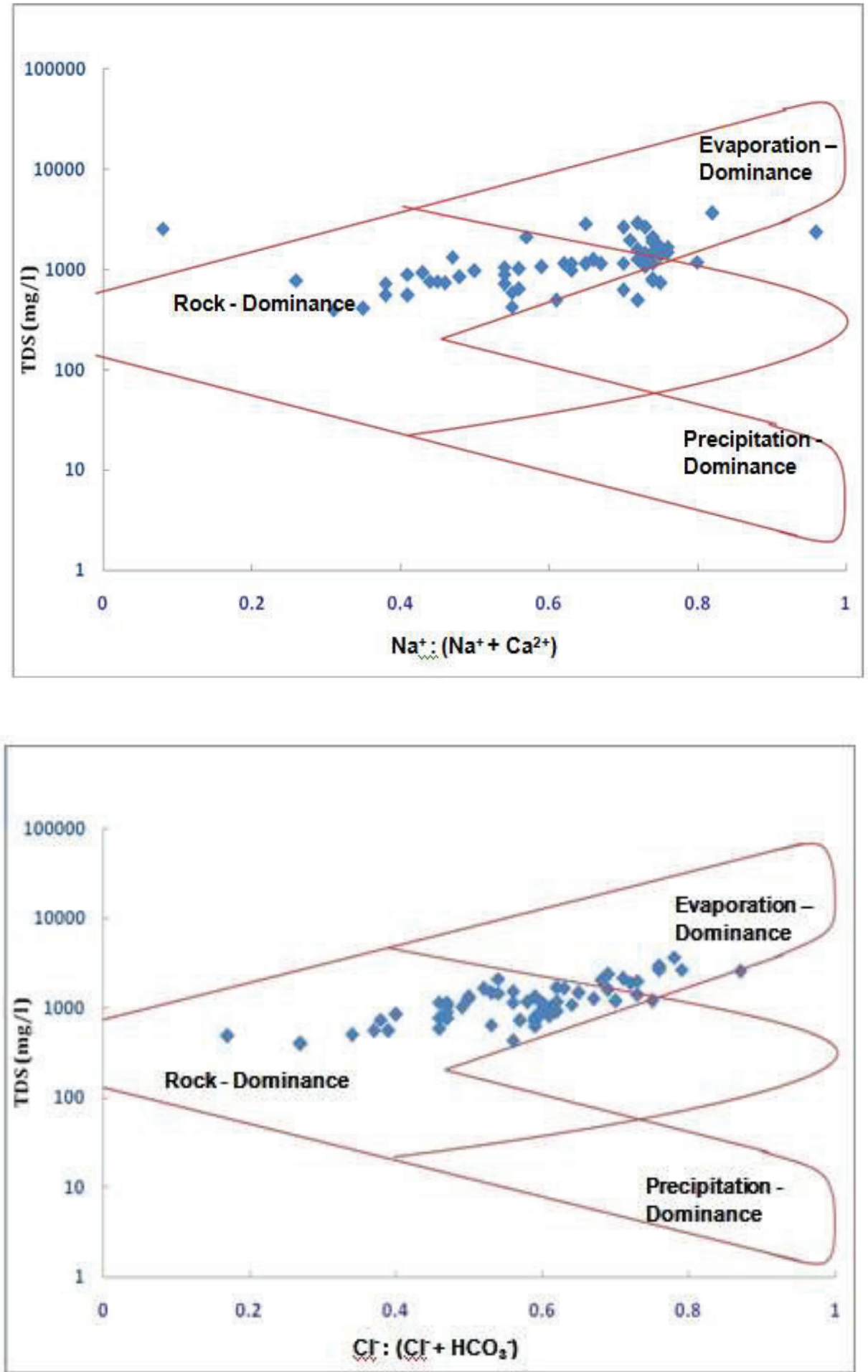

Fig. 5: Mechanism controlling of groundwater. 
The concentration of major ions of the groundwater samples has been used to categorize groundwater into different types based on main cations and anions. The majority of the graphical methods have been intended to simultaneously represent the TDS concentrations and the relative extent of certain major ions. Piper diagram is generally used graphically to understand the problem concerning the geochemical assessment of groundwater. The diagram (Fig. 6) shows the different water types such as calcium-sodium-bicarbonate-chloride $\left(\mathrm{Ca}-\mathrm{Na}-\mathrm{HCO}_{3}-\mathrm{Cl}\right)$, sodium-bicarbonate-chloride $\left(\mathrm{Na}-\mathrm{HCO}_{3}-\mathrm{Cl}\right)$, calcium-sodium-chloride $(\mathrm{Ca}-\mathrm{Na}-\mathrm{Cl})$, calcium-bicarbonate-chloride $\left(\mathrm{Ca}-\mathrm{HCO}_{3}-\mathrm{Cl}\right)$, calcium-bicarbonate $\left(\mathrm{Ca}-\mathrm{HCO}_{3}\right)$, calcium-sodium-bicarbonate $(\mathrm{Ca}-\mathrm{Na}-$ $\left.\mathrm{HCO}_{3}\right)$ and calcium-chloride $(\mathrm{Ca}-\mathrm{Cl})$. The abundance of the cations and anions based on dominance is given in Table 2 . Substratum containing fluoride minerals is usually respon-

Table 2: Relative abundance of major cations and anions for groundwater samples.

\begin{tabular}{|c|c|c|c|c|}
\hline S1. No. & Cations & $\%$ of samples & Anions & $\%$ of samples \\
\hline 1. & $\mathrm{Na}>\mathrm{Ca}>\mathrm{K}>\mathrm{Mg}$ & 30.68 & $\mathrm{HCO}_{3}>\mathrm{Cl}>\mathrm{SO}_{4}>\mathrm{NO}_{3}$ & 24.17 \\
\hline 2. & $\mathrm{Na}>\mathrm{Ca}>\mathrm{Mg} \mathrm{K}$ & 24.19 & $\mathrm{HCO}_{3}>\mathrm{C} 1>\mathrm{NO}_{3}>\mathrm{SO}_{4}$ & 20.97 \\
\hline 3. & $\mathrm{Ca}>\mathrm{Na}>\mathrm{Mg}>\mathrm{K}$ & 11.29 & $\mathrm{Cl}>\mathrm{HCO}_{3}>\mathrm{SO}_{4}>\mathrm{NO}_{3}$ & 25.81 \\
\hline 4. & $\mathrm{Na}>\mathrm{K}>\mathrm{Ca}>\mathrm{Mg}$ & 09.68 & $\mathrm{Cl}>\mathrm{HCO}_{3}>\mathrm{NO}_{3}>\mathrm{SO}_{4}$ & 11.29 \\
\hline 5. & $\mathrm{Ca}>\mathrm{Na}>\mathrm{K}>\mathrm{Mg}$ & 01.62 & $\mathrm{NO}_{3}>\mathrm{HCO}_{3}>\mathrm{Cl}>\mathrm{SO}_{4}$ & - \\
\hline 6. & $\mathrm{Ca}>\mathrm{Mg}>\mathrm{Na}>\mathrm{K}$ & 12.90 & $\mathrm{HCO}_{3}>\mathrm{NO}_{3}>\mathrm{Cl}>\mathrm{SO}_{4}$ & 01.62 \\
\hline 7. & $\mathrm{Mg}>\mathrm{Ca}>\mathrm{Na}>\mathrm{K}$ & 03.22 & $\mathrm{HCO}_{3}>\mathrm{SO}_{4}>\mathrm{Cl}>\mathrm{NO}_{3}$ & 06.45 \\
\hline 8. & $\mathrm{Na}>\mathrm{Mg}>\mathrm{Ca}>\mathrm{K}$ & 04.80 & $\mathrm{Cl}>\mathrm{SO}_{4}>\mathrm{HCO}_{3}>\mathrm{NO}_{3}$ & 08.07 \\
\hline 9 & $\mathrm{Mg}>\mathrm{Na}>\mathrm{K}>\mathrm{Ca}$ & 01.62 & $\mathrm{SO}_{4}>\mathrm{Cl}>\mathrm{NO}_{3}>\mathrm{HCO}_{3}$ & 01.62 \\
\hline
\end{tabular}

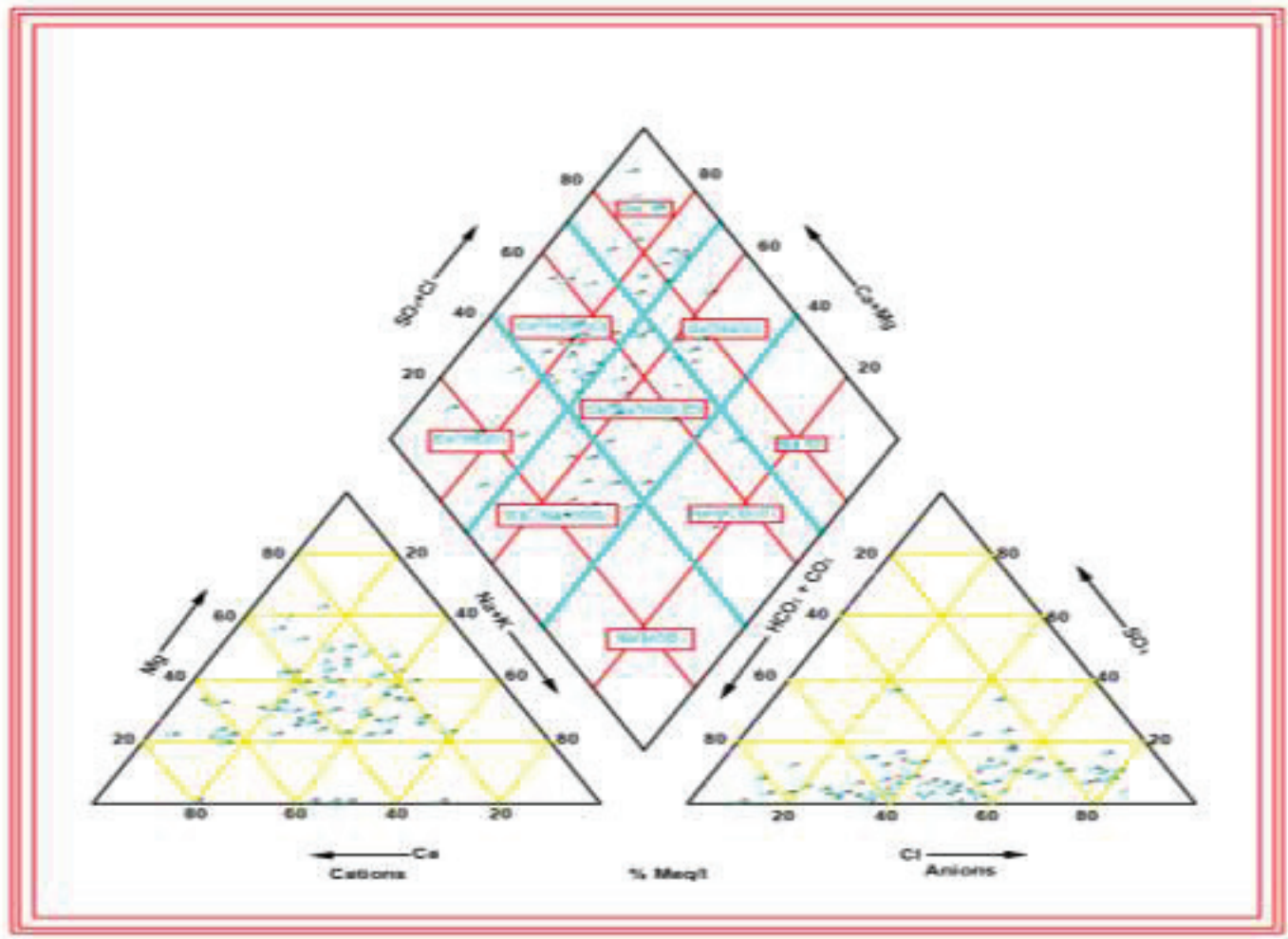

Fig. 6: Piper diagram depicting hydrochemical facies of groundwater. 
sible for a high concentration of the ion in groundwater and industrial contaminations of the atmosphere and vegetation by fluoride have been a severe problem. Small doses $(0.5$ to $1.00 \mathrm{mg} / \mathrm{L}$ ) have a significant influence on the dental system, while in higher doses $(>1.5 \mathrm{mg} / \mathrm{L})$, causes issues of dental fluorosis and gastrointestinal fluorosis (Sahu \& Vaishnav 2006). The fluoride concentration of the groundwater samples ranges from 0 to $2.11 \mathrm{mg} / \mathrm{L}$ with the mean value of $0.71 \mathrm{mg} / \mathrm{L}$.

\section{CONCLUSION}

The hydro-chemical parameter analysis of the investigation reveals that the study region is alkaline. Noyyal and Nallar river basins are more affected by anthropogenic activities. The order of abundance of the cations is $\mathrm{Ca}^{2+}>\mathrm{Mg}^{2+}>\mathrm{Na}^{+}$ $>\mathrm{K}^{+}$and anions is $\mathrm{Cl}^{-}>\mathrm{HCO}_{3}{ }^{-}>\mathrm{SO}_{4}{ }^{2-}>\mathrm{NO}_{3}{ }^{-}>\mathrm{CO}_{3}$. Based on the Piper diagram, the alkalies $\left(\mathrm{Na}^{+}\right.$and $\left.\mathrm{K}^{+}\right)$significantly exceed the alkaline earths $\left(\mathrm{Ca}^{2+}\right.$ and $\left.\mathrm{Mg}^{2+}\right)$, and strong acids $\left(\mathrm{Cl}^{-}\right.$and $\left.\mathrm{SO}_{4}{ }^{2-}\right)$ exceed the weak acids $\left(\mathrm{HCO}_{3}{ }^{-}\right.$and $\left.\mathrm{CO}_{3}\right)$. The distribution of the groundwater sample locations proves that the chemical weathering of the rock-forming minerals and evaporation process control the quality of groundwater in the study region. The investigation proves that most of the groundwater samples of the study area are not suitable for domestic use.

\section{REFERENCES}

Achwal, W.B. 1997. Problems during analysis of textile as per ecostandards and the customer articles ordinance (Part I), Colourage, 44: 29-31.

APHA 1995. Standard Methods for the Examination of Water and Wastewater, $17^{\text {th }}$ edn., American Public Health Association, Washington, DC.

Arumugam, K., Rajesh Kumar, A. and Elangovan, K. 2015. Evolution of hydrochemical parameters and quality assessment of groundwater in Tirupur Region, Tamil Nadu, India. Int. J. Environ. Res., 9: 1023-1036.

Davis, S.N. and Dewiest, J. M. 1996. Hydrogeology, Wiley, New York, 463.

Elangovan, K. and Rani, R. 2017. Study on suitability of groundwater for irrigation purpose in Parambikulam Aliyar project area, India. Indian Journal of Geomarine Science, 46(5): 1052-1060.

Freeze, R.A. and Cherry. J. A. 1979. Groundwater. Prentice-Hall, New Jersey.

Gibbs, R.J. 1970. Mechanism controlling world water chemistry. Science, 17: 1088-1090.

Hwang, J.Y., Park, S., Kim, H.K., Kim, M.S., Jo, H.J., Kim, J.I., Lee, G.M.,
Shin, I.K. and Kim, T.S. 2017. Hydrochemistry for the assessment of groundwater quality in Korea. Journal of Agricultural Chemistry and Environment, 6(1): 1-29.

ISI 2012. Status of Surface and Groundwater Resources. Bureau of Indian Standards, New Delhi, 2012.

Nwankwoala, H.O. and Udom, GJ. 2011. Hydro-chemical facies and ionic ratios of groundwater in Port Harcourt, Southern Nigeria. Research Journal of Chemical Sciences, 1(3): 87-101.

Raju, N.J. 2007. Hydrogeochemical parameters for assessment of groundwater quality in the upper Gunjanaeru River basin, Cuddapah District, Andhra Pradesh, South India. Environmental Geology, 52(6): 10671074.

Raju, N.J., Ram, P. and Gossel, W. 2014. Evaluation of groundwater vulnerability in the lower Varuna catchment area, Uttar Pradesh, India using AVI concept. Journal of the Geological Society of India, 83: 273-278.

Sahu, A. and Vaishnav, M.M. 2006. Study of fluoride in ground water around the BALCO, Kobra Area (India). Journal of Environ. Science and Engg., 48: 65-68.

Samson, S. and Elangovan, K. 2011. Assessment of groundwater quality for drinking purpose in Namakkal district, Tamil Nadu. India. Poll Res., 30: 85-94.

Santhosh, P. and Revath, D. 2014. Geochemical studies on the quality of groundwater in Tirupur District, Tamilnadu, India. Journal of Chemical, Biological and Physical Sciences, 4: 1780-1786.

Selvarani, G. A. and Elangovan, K. 2009. Hydrogeochemistry analysis of groundwater in Noyyal river basin, Tamilnadu, India. International Journal of Applied Environmental Sciences, 4: 211-227.

Solomon, S. and Quiel, F. 2006. Groundwater study using remote sensing and geographic information systems (GIS) in the central highlands of Eritrea. Hydrogeology Journal, 14(6): 1029-1041.

Subba Rao, N. 2006. Seasonal variation of groundwater in parts of Guntur District, Andhra Pradesh, India. Environmental Geology, 49: 413-429.

Subramani, T., Elango, L. and Damodarasamy, S.R. 2005. Groundwater quality and its suitability for drinking and agricultural use in Chithar River Basin, Tamil Nadu, India. Environ. Geol., 47: 1099-1110.

Sujatha, D. and Reddy, B.R. 2003. Quality characterization of groundwater in the south-eastern part of the Ranga Reddy district, Andhra Pradesh, India. Environmental Geology, 44(5): 579-586.

Toumi, N., Hussein, B.H. and Rafrafi, S. 2015. Groundwater quality and hydrochemical properties of Al-Ula region, Saudi Arabia. Environmental Monitoring and Assessment, 187(3): 84.

Umar, A., Umar, R. and Ahmad, M.S., 2001. Hydrogeological and hydrochemical framework of regional aquifer system in Kali-Ganga sub-basin, India. Environmental Geology, 40(4-5): 602-611.

Villegas-Navarro, A., RammHrez-M, Y., Salvador-S, M.S. and Gallardo, J.M. 2001. Determination of wastewater $\mathrm{LC}_{50}$ of the different process stages of the textile industry. Ecotoxicology and Environmental Safety, 48: 55-61.

WHO 1993. Guidelines for Drinking Water Quality, Vo.1, Recommendations, 2nd Edn., World Health Organization, Geneva. 